\title{
Computational investigation of Schiff bases from tryptamine as COX-2 inhibitors with potential anti-inflammatory activity
}

\author{
Estudo computacional de bases de Schiff da triptamina como \\ inibidores da COX-2 com potencial atividade anti-inflamatória
}

\section{Investigación computacional de las bases de Schiff de la triptamina como inhibidores de COX-2 con potencial actividad antiinflamatoria}

\author{
Ricardo Silva Porto ${ }^{1}$ (D) \\ 1 Federal University of Alagoas, Maceió, Alagoas, Brazil. \\ Corresponding author: \\ Ricardo Silva Porto \\ E-mail: portto@iqb.ufal.br \\ How to cite: Porto, R. S. (2022). Computational investigation of Schiff bases from tryptamine as COX-2 inhibitors \\ with potential anti-inflammatory activity. Journal of Research and Knowledge Spreading, 3(1), e13081. \\ http://dx.doi.org/10.20952/jrks3113081
}

\section{ABSTRACT}

Non-steroidal anti-inflammatory drugs are the most used drugs to inhibit cyclooxygenases (COX). Understanding the structure of COX isoforms is required for the research for more selective and less toxic anti-inflammatory agents. Also, computational methods can help to predict drug interaction. In this work, tryptamine Schiff bases, retrieved from literature, were screened to evaluate their ADMET profiles. After the initial screening, the compounds with better parameters were subjected to molecular docking interactions with the crystal structure of the COX-2 enzyme to verify binding affinities and the compound's disposition as antiinflammatory drugs. All compounds obeyed the Veber rule, and only one of them violated the Lipinski rule. Additionally, ten tryptamine Schiff bases presented equal or fewer toxicity alerts than Celecoxib $(\leq 1)$. The binding affinities obtained through molecular docking for these Schiff bases varied from -9.974 to $-8.765 \mathrm{kcal} / \mathrm{mol}$. The results demonstrated that the chosen compounds showed higher binding affinities when compared to Celecoxib $(-8.655 \mathrm{kcal} / \mathrm{mol})$; this suggests a significant ability to inhibit the COX-2 enzyme. It has been proposed that the presence of phenolic hydroxyl is significant for the observed binding affinities. The results of this study indicate that tryptamine Schiff bases are promising candidates to treat inflammatory disorders, with the potential to be used as suitable medicines for pain and inflammation treatment.

Keywords: Tryptamine. COX-2 inhibitors. Molecular docking. Schiff bases. 


\section{RESUMO}

Os anti-inflamatórios não esteroidais são os medicamentos mais utilizados para inibir as ciclooxigenases (COX). 0 entendimento da estrutura das isoformas COX é necessário para a pesquisa de agentes anti-inflamatórios mais seletivos e menos tóxicos. Além disso, os métodos computacionais podem ajudar a prever a interação medicamentosa. Neste trabalho, bases de Schiff da triptamina, extraídas da literatura, foram selecionadas para avaliar seus perfis ADMET. Após triagem inicial, os compostos com melhores parâmetros foram submetidos a interações de docking molecular com a estrutura cristalina da enzima COX-2 para verificar as afinidades de ligação e a disposição dos compostos como fármacos anti-inflamatórios. Todos os compostos obedeceram à regra de Veber e apenas um deles violou a regra de Lipinski. Adicionalmente, dez bases de Schiff da triptamina apresentaram alerta de toxicidade iguais ou menores que o Celecoxibe $(\leq 1)$. As afinidades de ligação obtidas por docking molecular para essas bases de Schiff variaram de $-9,974$ a $-8,765 \mathrm{kcal} /$ mol. Os resultados demonstraram que os compostos escolhidos apresentaram maiores afinidades de ligação quando comparados ao Celecoxib (-8,655 kcal / mol); isso sugere uma capacidade significativa de inibir a enzima COX2. É proposto que a presença de hidroxila fenólica é significativa para as afinidades de ligação observadas. Os resultados deste estudo indicam que as bases de Schiff da triptamina são candidatas promissoras para o tratamento de doenças inflamatórias, com potencial para serem utilizadas como medicamentos adequados para o tratamento da dor e inflamação.

Palavras-chave: Triptamina. Inibidores de COX-2. Docking molecular. Bases de Schiff.

\section{RESUMEN}

Los antiinflamatorios no esteroideos son los fármacos más utilizados para inhibir las ciclooxigenasas (COX). La comprensión de la estructura de las isoformas de la COX es necesaria para la investigación de agentes antiinflamatorios más selectivos y menos tóxicos. Además, los métodos computacionales pueden ayudar a predecir las interacciones entre medicamentos. En este trabajo se analizaron bases de Schiff de triptamina, extraídas de la literatura, para evaluar sus perfiles ADMET. Tras el cribado inicial, los compuestos con los mejores parámetros se sometieron a interacciones de docking molecular con la estructura cristalina de la enzima COX2 para verificar las afinidades de unión y la disposición del compuesto como agente antiinflamatorio. Todos los compuestos obedecían la regla de Veber, y sólo un compuesto violaba la regla de Lipinski. Además, diez bases triptamínicas de Schiff presentaron alertas de toxicidad iguales o inferiores a las del Celecoxib $(\leq 1)$. Las afinidades de unión obtenidas por docking molecular para estas bases Schiff oscilaron entre $-9,974$ y $-8,765 \mathrm{kcal} / \mathrm{mol}$. Los resultados mostraron que los compuestos elegidos mostraron afinidades de unión más altas en comparación con el Celecoxib (-8,655 kcal / mol); esto sugiere una capacidad significativa para inhibir la enzima COX-2. Se ha propuesto que la presencia de hidroxilos fenólicos es significativa para las afinidades de unión observadas. Los resultados de este estudio indican que las bases de Schiff triptamina son candidatos prometedores para el tratamiento de trastornos inflamatorios, con el potencial de ser utilizados como fármacos adecuados para el tratamiento del dolor y la inflamación.

Traducción realizada con la versión gratuita del traductor www.DeepL.com/Translator

Palabras clave: Triptamina. Inhibidores de COX-2. Acoplamiento molecular. Bases de Schiff.

\section{INTRODUCTION}

Non-steroidal anti-inflammatory drugs (NSAIDs) are among the most widespread drug classes globally, used to treat acute and chronic pain resulting from an inflammatory process (Wehling, 2014). The compounds mechanism in this therapeutic class involves inhibiting the 
enzyme arachidonate cyclooxygenase (COX). This enzyme has a significant role in synthesizing prostanoids and thromboxanes (Samad et al., 2002; Moreira et al., 2009). Prostanoids are cellular mediators that modulate a variety of physiological and pathological processes through cell membrane receptors. Thus, these substances have a crucial homeostatic function in organisms and their synthesis is induced at conditions such as inflammation and cancer. (Pasparakis, 2009).

Thus, by COX inhibition, NSAIDs can produce therapeutic effects, though they might cause adverse effects such as ulcerations, bleeding, perforations, and gastrointestinal obstructions to a greater or lesser extent (Moreira et al., 2009). Among the three known isoforms of the COX enzymes (COX-1, COX-2, and COX-3), the COX-2 isoform occurs through an induction mechanism that acts mainly in inflammatory cell membranes (Lúcio et al., 2008; Suleyman et al., 2007). In addition, it is a constitutive enzyme expressed in glomerular regions and small blood vessels in the kidneys, suggesting it is involved in physiological, cardiovascular and renal functions maintenance. Thus, comparing the active sites in COX-1 and COX-2, studies demonstrated that all amino acid residues are present in both enzymes. However, there is a difference at a specific position in these two isoforms, wherein the amino acid valine substitutes the COX-1 amino acid isoleucine position in the COX-2 (Simon, 1999; Salter et al., 2001). This difference could lead to a size change in the protein cavity where the drugs would bind. Also, in the co-crystallized structure of COX-1, the amino acid arginine, located close to the enzyme entrance channel, participates in the interaction (covalent bond) with the carboxylate ion present in conventional NSAIDs. Interestingly, this same residue does not interact with selective COX-2 inhibitors, which could benefit the advance in discovering new antiinflammatory agents in order to reduce toxicity and increase selectivity. Given this hypothesis, it is possible to plan and evaluate new non-steroidal anti-inflammatory drugs (NSAIDs) that can inhibit the COX-2 enzyme (Salter et al., 2001).

Tryptamine derivatives can have a high potential for different disorders treatment such as psychoactive, cancer, and vascular diseases (Araújo et al., 2015; Li et al., 2013; Weinstein et al., 2015). They have also presented antimalarial, antimicrobial, antiviral cytotoxic activities (Campos et al., 2019; Qu et al., 2011). Because of their importance and ease of access, these derivatives have been widely prepared through organic synthesis. They can be converted into natural products containing tryptamine scaffolds, such as psychotrimine (Newhouse \& Baran, 2008), (-)-Chimonanthine (Xie et al., 2013), and Trigonoliimine C (Qi et al., 2011). Schiff bases from tryptamine can be prepared by treating tryptamine with different aldehydes in the presence of methanol or ethanol in a weakly acidic environment (Tollari et al., 1998). A literature search showed that these Schiff bases have been prepared and evaluated for their antiulcer activity and also as nucleoside triphosphate diphosphohydrolases (NTPDases), thus potentially treating thrombosis and cancer (Mustafa et al., 2009; Kahn et al., 2019).

In a project searching to identify compounds that may serve as leads for designing new non-steroidal anti-inflammatory drugs, the present work aims at screening Schiff bases derived from tryptamine as anti-inflammatory agents to inhibit COX-2 isoform. As tools to perform the screening of the selected Schiff bases, ADMET predictions were performed in order to evaluate their pharmacokinetic and toxicological profiles. Subsequently, molecular docking of selected compounds was carried out to estimate the binding affinities into the active site of COX-2.

\section{METHODOLOGY}

The chemical structure searching of the tryptamine Schiff bases was accomplished using Scifinder (https://scifinder.cas.org/), with the keywords "tryptamine derivatives" and "Schiff bases", and the results ranked in order of relevance. Thirty compounds from three articles were retrieved from the database. The chemical structure of compounds was built using Chemdraw Ultra version 12.0 (Cousins, 2011). Three-dimensional structures were generated by Chem3D 
and optimized by MMFF94s force field (Wahl et al., 2019), implemented in the freeware Avogadro® version 1.2.0 (Hanwell et al., 2012).

To get an insight of potential anti-inflammatory activity of tryptamine derivatives, these compounds were docked into the active site of the cyclooxygenase-2 (PDB ID: 3NTG). DockThor, a free web server for protein-ligand docking (https://dockthor.lncc.br/), was used to perform molecular docking for studying the binding affinities of the compounds (Santos et al., 2020). To evaluate docking accuracy, the re-docking process was performed. Alignment of the best pose of ligand D72 in the active site of cyclooxygenase- 2 was achieved with an RMSD value of 0.775 ( $\leq 2.0 \AA$ from the experimental one). The highest scored docking poses were analyzed and the distances were measured using Discovery Studio Visualizer (Jejurikar et al., 2012).

Physicochemical and pharmacokinetic properties of the best-docked Schiff bases were performed by using SwissADME website (Daina et al., 2017). The toxicological profile of the compounds was evaluated through the freely accessible pkCSM online application (Pires et al., 2015). By applying this tool, diverse toxicity parameters were predicted. Canonical smiles were used for ADMET in silico analysis.

\section{RESULTS AND DISCUSSION}

\section{Ligand screening and ADMET properties for selected compounds}

The Scifinder search for tryptamine Schiff bases resulted in thirty compounds (Tollari et al., 1998; Mustafa et al., 2009; Kahn et al., 2019). The ADME prediction of these compounds was performed in the SwissAdme web tool and is depicted in Table 1, together with the parameters of reference drug Celecoxib. As can be seen in the table, all compounds obeyed the Veber rule (NRB $\leq 10$ and TPSA $\leq 140 \AA$ ), and only TRP07 violated the Lipinski rule (HBD $\leq 5, \mathrm{HBA} \leq$, MW $<500 \mathrm{Da}$, cLOGP $\leq 5$ ), suggesting that, in general, tryptamine Schiff bases present good bioavailability (Baurin et al., 2004). Water solubility (Log $S$ ) predictions showed that the tryptamine Schiff bases have, in general, good to moderate solubility $(-6<\log S<-2)$, and therefore have sufficient solubility to meet the requirements of pharmacokinetics (Jorgensen \& Duffy, 2002). Skin permeation ( $\log K p$ ) is used in industry to determine the toxicity of a molecule in the case of accidental skin contact. The more negative the log $K p$, the less skin permeant is the molecule (Karadzovska et al., 2013). The results suggest that most compounds have a low propensity to permeate the skin. The SwissADME was also used to predict the compound's ability of being absorbed by the gastrointestinal tract (GIA) and cross the bloodbrain barrier (BBB) (Tripathi et al., 2019). All Schiff bases showed high gastrointestinal absorption and, with a few exceptions, the compounds are also prone to permeate into the brain.

Some toxicological parameters were also evaluated for the tryptamine Schiff bases and the results are shown in table 2.17 out of 29 compounds did not show toxicity alert for Ames mutagenicity and only 6 compounds showed the maximum tolerated dose (in humans) above reference value. hERG potassium channels are crucial for regular electrical activity in the heart. Inherited anomaly in the hERG gene may cause long QT syndrome, in which the individual will be predisposed to life-threatening arrhythmias (Sanguinetti \& Tristani-Firouzi, 2006). Inhibition of hERG channels has resulted in withdrawal of many substances from the market. No compound was predicted to inhibit hERG channel. In continuation, 9 compounds were predicted be hepatotoxic and no compound was prone to be allergic to the skin. In this way, the compounds that presented equal or less alerts than Celecoxib ( 0 or 1 alert) were further considered for molecular docking studies. 
Table 1. ADME predictions of the Tryptamine Schiff Bases.

\begin{tabular}{|c|c|c|c|c|c|c|c|c|c|c|}
\hline Compound & M.W. & $c \log \mathrm{P}$ & HBD & HBA & NRB & TPSA & $\log S$ & $\log K p$ & GIA & BBB \\
\hline Celecoxib & 381.37 & 3.40 & 1 & 7 & 4 & 86.36 & -4.57 & -6.21 & High & No \\
\hline TRP01 & 317.21 & 4.62 & 1 & 1 & 4 & 28.15 & -5.08 & -4.84 & High & Yes \\
\hline TRP02 & 327.22 & 4.15 & 1 & 1 & 4 & 28.15 & -4.81 & -5.31 & High & Yes \\
\hline TRP03 & 282.77 & 4.05 & 1 & 1 & 4 & 28.15 & -4.50 & -5.08 & High & Yes \\
\hline TRP04 & 383.28 & 4.52 & 1 & 2 & 6 & 45.22 & -5.28 & -5.26 & High & Yes \\
\hline TRP05 & 373.28 & 5.00 & 1 & 2 & 6 & 45.22 & -5.55 & -4.80 & High & Yes \\
\hline TRP06 & 359.25 & 4.65 & 1 & 2 & 5 & 45.22 & -5.26 & -5.05 & High & Yes \\
\hline TRP07 & 416.34 & 5.04 & 1 & 2 & 8 & 48.46 & -5.67 & -5.03 & High & Yes \\
\hline TRP08 & 309.32 & 2.41 & 2 & 4 & 5 & 94.20 & -3.83 & -6.02 & High & No \\
\hline TRP09 & 376.53 & 5.56 & 2 & 2 & 6 & 48.38 & -6.31 & -3.93 & High & No \\
\hline TRP10 & 298.77 & 3.71 & 2 & 2 & 4 & 48.38 & -4.38 & -5.39 & High & Yes \\
\hline TRP11 & 238.28 & 2.95 & 1 & 2 & 4 & 41.29 & -3.47 & -5.68 & High & Yes \\
\hline TRP12 & 298.38 & 4.50 & 1 & 1 & 4 & 28.15 & -5.04 & -4.73 & High & Yes \\
\hline TRP13 & 264.32 & 3.19 & 2 & 2 & 4 & 48.38 & -3.77 & -5.66 & High & Yes \\
\hline TRP14 & 343.22 & 3.79 & 2 & 2 & 4 & 48.38 & -4.70 & -5.61 & High & Yes \\
\hline TRP15 & 314.38 & 4.11 & 2 & 2 & 4 & 48.38 & -4.93 & -5.04 & High & Yes \\
\hline TRP16 & 333.21 & 4.27 & 2 & 2 & 4 & 48.38 & -4.93 & -5.19 & High & Yes \\
\hline TRP17 & 308.37 & 3.55 & 1 & 3 & 6 & 46.61 & -4.06 & -5.68 & High & Yes \\
\hline TRP18 & 294.41 & 4.12 & 1 & 1 & 5 & 53.45 & -4.41 & -5.23 & High & Yes \\
\hline TRP19 & 280.32 & 2.80 & 3 & 3 & 4 & 68.61 & -3.61 & -6.01 & High & Yes \\
\hline TRP20 & 294.35 & 3.20 & 2 & 3 & 5 & 57.61 & -3.86 & -5.82 & High & Yes \\
\hline TRP21 & 282.31 & 3.49 & 2 & 3 & 4 & 48.38 & -3.95 & -5.66 & High & Yes \\
\hline TRP22 & 294.35 & 3.18 & 2 & 3 & 5 & 57.61 & -3.86 & -5.82 & High & Yes \\
\hline TRP23 & 373.24 & 3.81 & 2 & 3 & 5 & 57.61 & -4.76 & -5.81 & High & Yes \\
\hline TRP24 & 282.31 & 3.49 & 2 & 3 & 4 & 48.38 & -3.95 & -5.66 & High & Yes \\
\hline TRP25 & 294.35 & 3.18 & 2 & 3 & 5 & 57.61 & -3.86 & -5.82 & High & Yes \\
\hline TRP26 & 373.24 & 3.81 & 2 & 3 & 5 & 57.61 & -4.76 & -5.81 & High & Yes \\
\hline TRP27 & 324.37 & 3.19 & 2 & 4 & 6 & 66.84 & -3.88 & -6.07 & High & Yes \\
\hline TRP28 & 280.32 & 2.77 & 3 & 3 & 4 & 68.61 & -3.61 & -6.01 & High & Yes \\
\hline TRP29 & 298.77 & 3.77 & 2 & 2 & 4 & 48.38 & -4.35 & -5.42 & High & Yes \\
\hline TRP30 & 377.66 & 4.36 & 2 & 2 & 4 & 48.38 & -5.25 & -5.42 & High & Yes \\
\hline
\end{tabular}

MW: molecular weight; HBD: hydrogen bond donor; HBA: hydrogen bond acceptor; NRB: number of rotatable bonds; TPSA: topological polar surface area; GIA: gastrointestinal absorption; BBB: ability to cross the bloodbrain barrier 
Table 2. Toxicological predictions of the Tryptamine Schiff Bases.

\begin{tabular}{|c|c|c|c|c|c|c|c|c|c|}
\hline Compoud & Ames & MTD & hERG & ORAT & ORCT & Hep & SS & MT & Alerts \\
\hline Des. val & No & $\leq 0.477$ & No & & & No & No & $\geq-0.3$ & \\
\hline Celecoxib & No & 0.157 & No & 2.317 & 1.447 & Yes & No & 0.191 & 1 \\
\hline TRP01 & No & 0.53 & No & 2.34 & 1.40 & No & No & -1.872 & 2 \\
\hline TRP02 & No & 0.54 & No & 2.21 & 1.45 & No & No & -1.501 & 2 \\
\hline TRP03 & No & 0.54 & No & 2.20 & 1.48 & No & No & -1.355 & 2 \\
\hline TRP04 & Yes & 0.472 & No & 2.44 & 0.63 & Yes & No & -1.789 & 3 \\
\hline TRP05 & Yes & 0.456 & No & 2.58 & 0.94 & Yes & No & -2.143 & 3 \\
\hline TRP06 & No & 0.355 & No & 2.57 & 0.98 & Yes & No & -1.44 & 2 \\
\hline TRP07 & No & 0.408 & No & 2.91 & 1.687 & Yes & No & -2.218 & 2 \\
\hline TRP08 & Yes & 0.191 & No & 3.11 & 1.656 & No & No & -0.897 & 2 \\
\hline TRP09 & No & 0.159 & No & 2.40 & 1.354 & No & No & -2.713 & 1 \\
\hline TRP10 & No & 0.431 & No & 2.32 & 1.447 & No & No & -1.063 & 1 \\
\hline TRP11 & Yes & 0.06 & No & 2.573 & 0.805 & No & No & 1.192 & 1 \\
\hline TRP12 & Yes & 0.703 & No & 1.649 & 0.515 & No & No & -1.154 & 3 \\
\hline TRP13 & Yes & 0.447 & No & 2.186 & 1.547 & No & No & -0.696 & 2 \\
\hline TRP14 & Yes & 0.429 & No & 2.324 & 1.413 & No & No & -1.209 & 2 \\
\hline TRP15 & Yes & 0.636 & No & 1.962 & 1.22 & No & No & -2.046 & 3 \\
\hline TRP16 & No & 0.443 & No & 2.44 & 1.16 & No & No & -1.59 & 1 \\
\hline TRP17 & Yes & 0.376 & No & 2.36 & 1.47 & Yes & No & -2.797 & 3 \\
\hline TRP18 & No & 0.572 & No & 2.215 & 1.361 & Yes & No & -1.437 & 3 \\
\hline TRP19 & No & 0.059 & No & 2.186 & 1.214 & No & No & -0.098 & 0 \\
\hline TRP20 & Yes & 0.185 & No & 2.132 & 1.439 & No & No & -1.221 & 2 \\
\hline TRP21 & Yes & 0.258 & No & 2.245 & 1.256 & No & No & -1.486 & 2 \\
\hline TRP22 & No & 0.298 & No & 2.373 & 1.426 & Yes & No & -1.88 & 2 \\
\hline TRP23 & No & 0.344 & No & 2.456 & 1.618 & No & No & -2.386 & 1 \\
\hline TRP24 & Yes & 0.424 & No & 2.33 & 1.398 & No & No & -1.482 & 2 \\
\hline TRP25 & No & 0.321 & No & 2.44 & 1.659 & No & No & -2.526 & 1 \\
\hline TRP26 & No & 0.53 & No & 2.133 & 1.778 & No & No & -2.071 & 1 \\
\hline TRP27 & No & 0.133 & No & 2.368 & 1.411 & Yes & No & -2.738 & 2 \\
\hline TRP28 & No & 0.131 & No & 2.289 & 1.455 & No & No & -0.228 & 0 \\
\hline TRP29 & No & 0.425 & No & 2.326 & 1.432 & No & No & -1.336 & 1 \\
\hline TRP30 & Yes & 0.66 & No & 1.841 & 0.133 & No & No & -2.422 & 3 \\
\hline
\end{tabular}

MTD: maximum tolerated dose; hERG: human Ether-à-go-go-Related Gene; ORAT: Oral rat acute toxicity; ORCT: Oral rat chronic toxicity; Hep: Hepatotoxicity; SS: skin sensitization; MT: Minnow toxicity 


\section{Molecular Docking Studies of Tryptamine Schiff Bases}

Docking simulations were performed to advance the understanding of the possible interactions that result in anti-inflammatory activities (Hassan et al., 2020). A total of ten Schiff bases from table 2 (alerts $\leq 1$ ) were subjected to docking studies with cyclooxygenase- 2 protein 3NTG (Wang et al., 2020) in DockThor (see appendix). The figure 1 shows the superimposition of all the 10 docked Schiff bases in the protein's binding pocket. The 5 compounds with the best affinities are shown in table 3. The predicted binding affinities for these compounds are disposed in decreasing order and varied from -9.974 to $-9.317 \mathrm{kcal} / \mathrm{mol}$. Our docking scores for the selected compounds were higher than Celecoxib (binding affinity $=-8.655 \mathrm{kcal} / \mathrm{mol}$.), a nonsteroidal analgesic, and anti-inflammatory from the class of specific inhibitors of the COX-2 enzyme (Abdel-Sayed et al., 2016), confirming the biological potential of these tryptamine derivatives. The figure 2 shows the interactions of compounds TRP23, TRP16 and TRP19 with the COX-2 enzyme, as well as the compound's fitting in the protein active site.

We can observe from the figure 2 that TRP23 interacts by hydrogen bond with ASN368 and HIS374, while TRP19 interacts also by hydrogen bond with TYR371. TRP16 binds to the binding site only via hydrophobic interactions with ALA185, HIS193, HIS372, TYR371, LEU376 and LEU377. Additionally, TRP23 presents hydrophobic interactions with HIS200, HIS193, HIS372, LEU377, LEU394, TYR371, VAL281 and VAL431. Finally TRP19 shows hydrophobic interactions with ALA108 and HIS372. Most of these interactions are similar to that observed for ursolic acid derivatives in the binding site (Deepthi et al., 2020), which presented promising in vitro anti-inflammatory activity. It's clear that the presence of phenolic hydroxyl groups is a major factor in the compound's ability to interact with the protein's binding site. The compounds with best binding affinities, as can be seen in table 3 present at least one phenolic hydroxyl. These hydroxyl moieties interact with amino acids in the active site by hydrogen bonding, hydrophobic interactions, or both.

Hence, molecular docking results reveal that synthetic tryptamine Schiff bases have proven potential compounds to inhibit cyclooxygenase 2. The 5 best docking-scored compounds, among those predicted to be potentially less toxic, exhibited higher binding affinities than Celecoxib. Furthermore, these compounds can be easily obtained from a fast and economical process, which involves a well-established condensation reaction, making them promising candidate drugs to treat inflammatory processes.

Figure 1. Superimposition of the 10 docked Schiff bases in the protein binding pocket

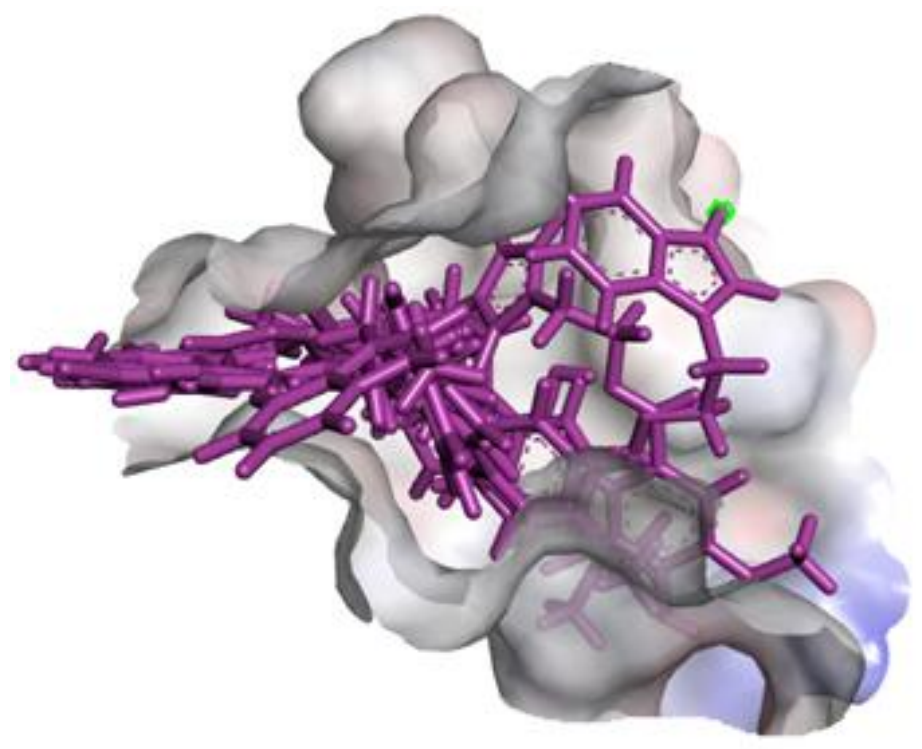


Table 3. Molecular docking simulations of the tryptamine Schiff bases.

Compoud Structure Binding Affinities (kcal / mol)

TRP23

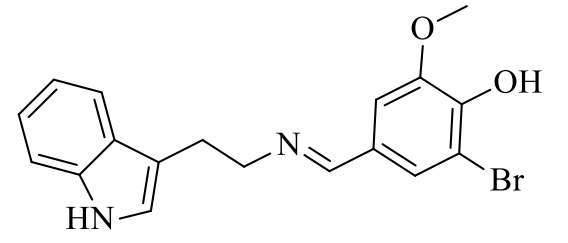

TRP16<smiles>Oc1c(Cl)cc(Cl)cc1/C=N/CCc1c[nH]c2ccccc12</smiles>

TRP19<smiles>Oc1ccc(/C=N/CCc2c[nH]c3ccccc23)cc1O</smiles>

TRP29<smiles>Oc1ccc(/C=N/CCc2c[nH]c3ccccc23)c(O)c1</smiles>

TRP10<smiles>Oc1ccc(Cl)cc1/C=N/CCc1c[nH]c2ccccc12</smiles>

\section{Celecoxib}<smiles>Cc1ccc(-c2cc(C(F)(F)F)nn2-c2ccc(S(N)(=O)=O)cc2)cc1</smiles> 
Figure 2. Molecular docking interactions of TRP23, TR16 and TRP28 with cyclooxygenase enzyme pocket 3NTG

TRP23
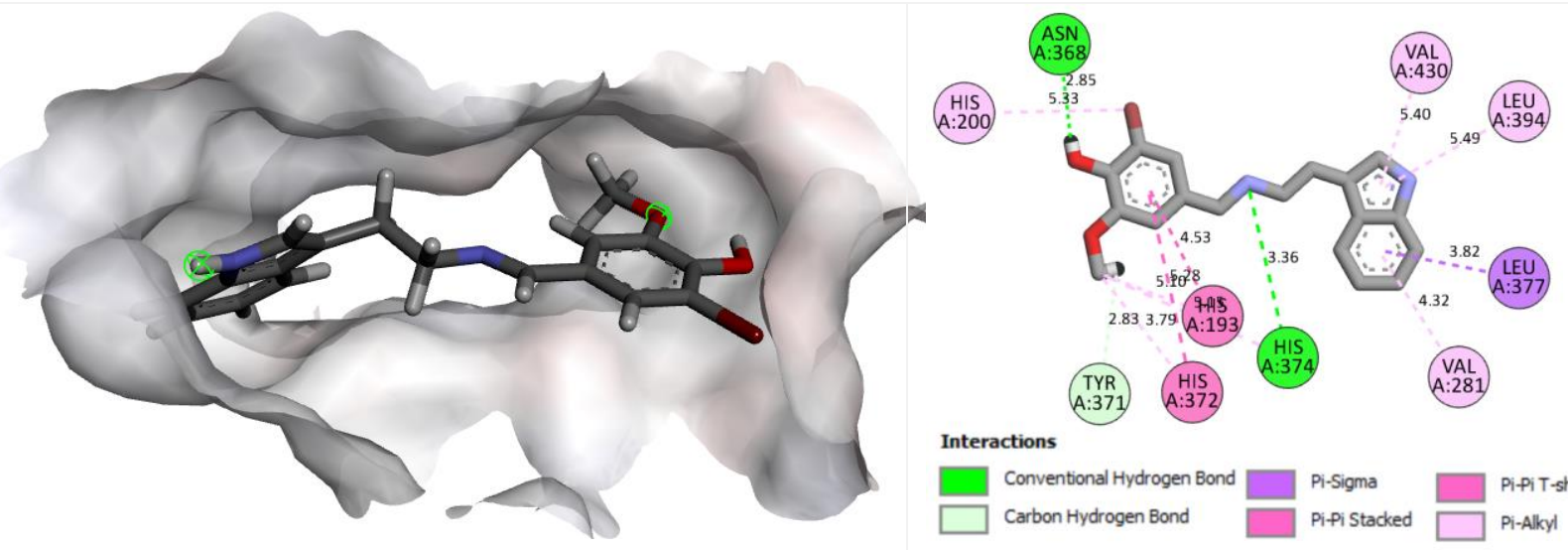

Interactions

Conventional Hydrogen Bond

Carbon Hydrogen Bond

Pi-Sigma

Pi-Pi Stacked

Pi-Pi T-shaped

Pi-Alkyl

TRP16
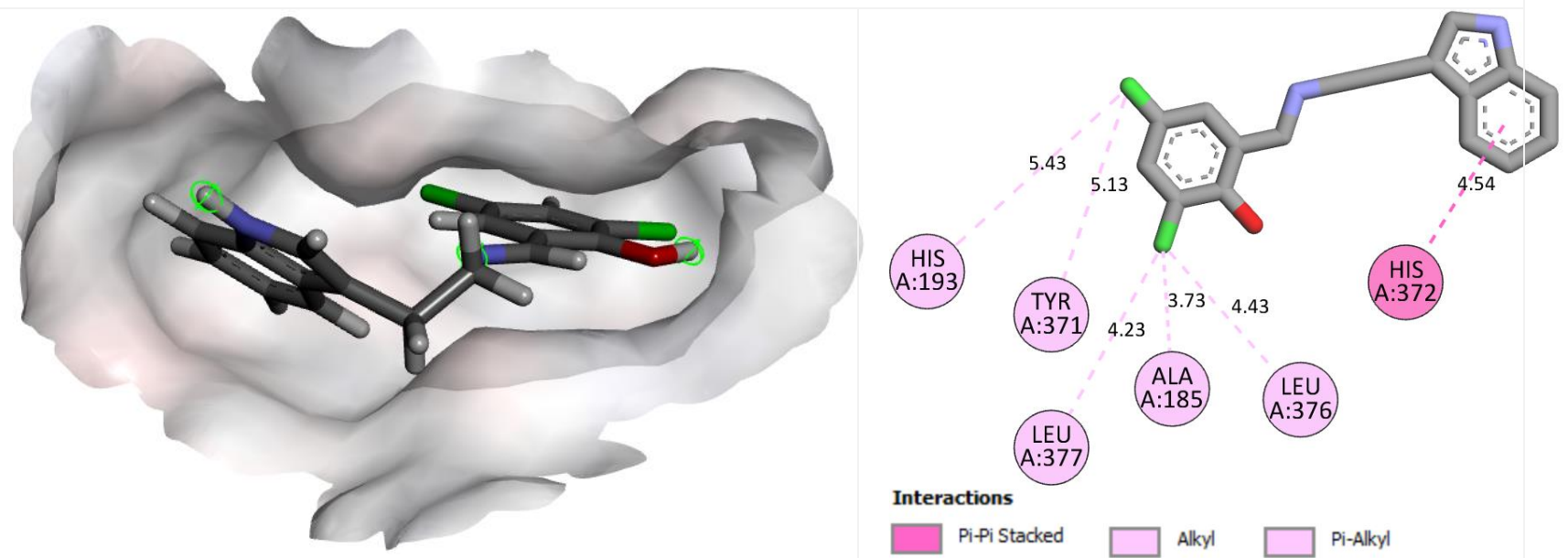

TRP19
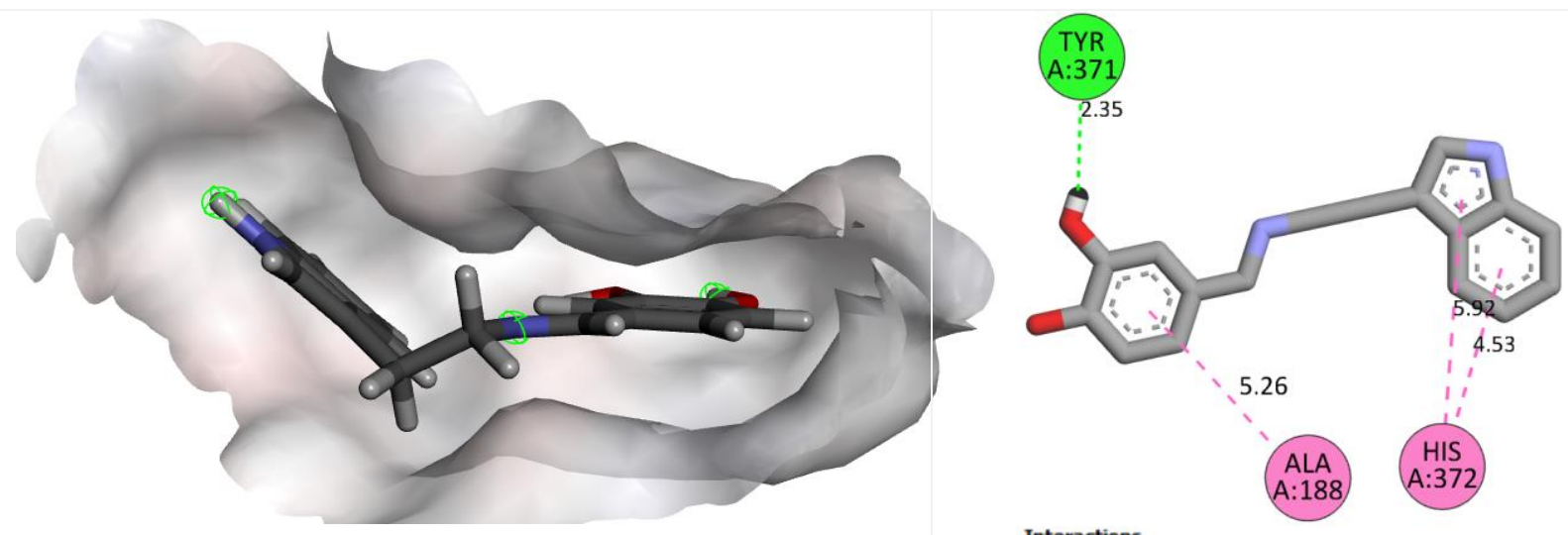

Interactions

van der Waals

Conventional Hydrogen Bond

The tryptamine represents a remarkable naturally occurring compound demonstrating diverse pharmacological activities. Furthermore, Schiff bases can be obtained by tryptamine 
reaction with different aromatic aldehydes. In this study, we accomplished a virtual screening through ADMET predictions and molecular docking. The evaluated compounds presented good pharmacokinetics; ten compounds were considered in further studies since they exhibit, like Celecoxib, few toxicological alerts. The remaining compounds were subjected to molecular docking studies. The results revealed that they showed better binding affinities in the cyclooxygenase 2 receptor compared to Celecoxib. Additionally, tryptamine Schiff bases emerge as low-cost anti-inflammatory alternatives in treating pain and inflammation, presenting suitable synthetic accessibility.

\section{ACKNOWLEDGMENTS: Not applicable.}

AUTHOR CONTRIBUTIONS: conception and design, acquisition of data, analysis and interpretation of data, drafting the article, critical review of important intellectual content. The author had read and approved the final version of the manuscript.

CONFLICTS OF INTEREST: The author declare that there are no conflicts of interest.

\section{REFERENCES}

Abdel-Sayed, M. A., Bayomi, S. M., El-Sherbeny, M. A., Abdel-Aziz, N. I., ElTahir, K. E. H., Shehatou, G. S., \& Alaa, A. M. (2016). Synthesis, anti-inflammatory, analgesic, COX-1/2 inhibition activities and molecular docking study of pyrazoline derivatives. Bioorganic \& medicinal chemistry, 24(9), 2032-2042.

https://doi.org/10.1016/i.bmc.2016.03.032

Araújo, A. M., Carvalho, F., de Lourdes Bastos, M., De Pinho, P. G., \& Carvalho, M. (2015). The hallucinogenic world of tryptamines: an updated review. Archives of Toxicology, 89(8), 1151-1173. https://doi.org/10.1007/s00204$\underline{015-1513-x}$

Baurin, N., Baker, R., Richardson, C., Chen, I., Foloppe, N., Potter, A., ... \& Hubbard, R. E. (2004). Drug-like annotation and duplicate analysis of a 23-supplier chemical database totalling 2.7 million compounds. Journal of chemical information and computer sciences, 44(2), 643-651. https://doi.org/10.1021/ci034260m

Campos, P. E., Pichon, E., Moriou, C., Clerc, P., Trépos, R., Frederich, M., ... \& Al-Mourabit, A. (2019). New antimalarial and antimicrobial tryptamine derivatives from the marine sponge Fascaplysinopsis reticulata. Marine drugs, 17(3), 167. https://doi.org/10.3390/md17030167

Cousins, K. R. (2011). Computer review of ChemDraw ultra 12.0., 133(21), 8388-8388. https://doi.org/10.1021/ja204075s

Daina, A., Michielin, O., \& Zoete, V. (2017). SwissADME: a free web tool to evaluate pharmacokinetics, druglikeness and medicinal chemistry friendliness of small molecules. Scientific reports, 7(1), 1-13.

https://doi.org/10.1038/srep42717

Deepthi, A., Krishnan, D., \& Sanju, A. (2020). Semisynthesis of ursolic acid-2-(2-thienylidene)-oxadiazole hybrid molecule and an evaluation of its COX inhibition property. Journal of Heterocyclic Chemistry, 57(4), 2048-2055. https://doi.org/10.1002/jhet.3923

Hanwell, M. D., Curtis, D. E., Lonie, D. C., Vandermeersch, T., Zurek, E., \& Hutchison, G. R. (2012). Avogadro: an advanced semantic chemical editor, visualization, and analysis platform. Journal of cheminformatics, 4(1), 1-17. https://doi.org/10.1186/1758-2946-4-17

Hassan, S. S. U., Zhang, W. D., Jin, H. Z., Basha, S. H., \& Priya, S. S. (2020). In-silico anti-inflammatory potential of guaiane dimers from Xylopia vielana targeting COX-2. Journal of Biomolecular Structure and Dynamics, 1-15. https://doi.org/10.1080/07391102.2020.1815579

Jejurikar, B. L., \& Rohane, S. H. (2021). Drug Designing in Discovery Studio. Asian Journal of Research in Chemistry, 14(2), 135-138. https://ajrconline.org/AbstractView.aspx?PID=2021-14-2-8 
Jorgensen, W. L., \& Duffy, E. M. (2002). Prediction of drug solubility from structure. Advanced drug delivery reviews, 54(3), 355-366. https://doi.org/10.1016/S0169-409X(02)00008-X

Karadzovska, D., Brooks, J. D., Monteiro-Riviere, N. A., \& Riviere, J. E. (2013). Predicting skin permeability from complex vehicles. Advanced drug delivery reviews, 65(2), 265-277. https://doi.org/10.1016/j.addr.2012.01.019

Khan, K. M., Salar, U., Afzal, S., Wadood, A., Taha, M., Perveen, S., ... \& Iqbal, J. (2019). Schiff bases of tryptamine as potent inhibitors of nucleoside triphosphate diphosphohydrolases (NTPDases): Structure-activity relationship. Bioorganic chemistry, 82, 253-266. https://doi.org/10.1016/j.bioorg.2018.10.046

Li, S., Jia, Y., Jacobson, B., McCauley, J., Kratzke, R., Bitterman, P. B., \& Wagner, C. R. (2013). Treatment of breast and lung cancer cells with a N-7 benzyl guanosine monophosphate tryptamine phosphoramidate pronucleotide (4Ei-1) results in chemosensitization to gemcitabine and induced eIF4E proteasomal degradation. Molecular pharmaceutics, 10(2), 523-531. https://doi.org/10.1021/mp300699d

Lúcio, M., Bringezu, F., Reis, S., Lima, J. L., \& Brezesinski, G. (2008). Binding of nonsteroidal anti-inflammatory drugs to DPPC: structure and thermodynamic aspects. Langmuir, 24(8), 4132-4139.

https://doi.org/10.1021/la703584s

Moreira, T. S. A., Cid, Y. P., Pierre, M. B. R., Sousa, V. P. D., Kummerle, A. E., \& Fraga, C. A. M. (2009). Extração e purificação de fármacos anti-inflamatórios não esteroidais ciclo-oxigenase-2 seletivos. Química Nova, 32, 13241328. https://doi.org/10.1590/S0100-40422009000500040

Mustafa, I. M., Hapipah, M. A., Abdulla, M. A., \& Ward, T. R. (2009). Synthesis, structural characterization, and antiulcerogenic activity of schiff base ligands derived from tryptamine and 5-chloro, 5-nitro, 3, 5-ditertiarybutyl salicylaldehyde and their nickel (II), copper (II), and zinc (II) complexes. Polyhedron, 28(18), 3993-3998. https://doi.org/10.1016/j.poly.2009.10.004

Newhouse, T., \& Baran, P. S. (2008). Total synthesis of ( \pm )-psychotrimine. Journal of the American Chemical Society, 130(33), 10886-10887. https://doi.org/10.1021/ja8042307

Pasparakis, M. (2009). Regulation of tissue homeostasis by NF- $\kappa$ B signalling: implications for inflammatory diseases. Nature Reviews Immunology, 9(11), 778-788. https://doi.org/10.1038/nri2655

Pires, D. E., Blundell, T. L., \& Ascher, D. B. (2015). pkCSM: predicting small-molecule pharmacokinetic and toxicity properties using graph-based signatures. Journal of medicinal chemistry, 58(9), 4066-4072.

https://doi.org/10.1021/acs.jmedchem.5b00104

Qi, X., Bao, H., \& Tambar, U. K. (2011). Total synthesis of ( \pm )-Trigonoliimine C via oxidative rearrangement of an unsymmetrical bis-tryptamine. Journal of the American Chemical Society, 133(26), 10050-10053. https://doi.org/10.1021/ja203960b

Qu, S. J., Wang, G. F., Duan, W. H., Yao, S. Y., Zuo, J. P., Tan, C. H., \& Zhu, D. Y. (2011). Tryptamine derivatives as novel non-nucleosidic inhibitors against hepatitis B virus. Bioorganic \& medicinal chemistry, $19(10), 3120-3127$. https://doi.org/10.1016/j.bmc.2011.04.004

Salter, E. A., Wierzbicki, A., Sperl, G., \& Thompson, W. J. (2001). Molecular modeling study of COX-2 inhibition by diarylheterocycles and sulindac sulfide. Journal of Molecular Structure: THEOCHEM, 549(1-2), 111-121. https://doi.org/10.1016/S0166-1280(01)00485-7

Samad, T. A., Sapirstein, A., \& Woolf, C. J. (2002). Prostanoids and pain: unraveling mechanisms and revealing therapeutic targets. Trends in molecular medicine, 8(8), 390-396. https://doi.org/10.1016/S14714914(02)02383-3

Sanguinetti, M. C., \& Tristani-Firouzi, M. (2006). hERG potassium channels and cardiac arrhythmia. Nature, 440(7083), 463-469. https://doi.org/10.1038/nature04710

Santos, K. B., Guedes, I. A., Karl, A. L., \& Dardenne, L. E. (2020). Highly flexible ligand docking: benchmarking of the DockThor program on the LEADS-PEP protein-peptide data set. Journal of Chemical Information and Modeling, 60(2), 667-683. https://doi.org/10.1021/acs.jcim.9b00905 
Simon, L. S. (1999). Role and regulation of cyclooxygenase-2 during inflammation. The American journal of medicine, 106(5), 37S-42S. https://doi.org/10.1016/S0002-9343(99)00115-1

Suleyman, H., Demircan, B., \& Karagoz, Y. (2007). Anti-inflammatory and side effects of cyclo-oxygenase inhibitors. Pharmacological reports, 59(3), 247. https://europepmc.org/article/med/17652824

Tollari, S., Cenini, S., Tunice, C., \& Palmisano, G. (1998). Cyclopalladated complexes of Schiff bases of homoveratrylamine and tryptamine. Synthesis and CO insertion. Inorganica chimica acta, 272(1-2), 18-23. https://doi.org/10.1016/S0020-1693(97)05846-5

Tripathi, P., Ghosh, S., \& Talapatra, S. N. (2019). Bioavailability prediction of phytochemicals present in Calotropis procera (Aiton) R. Br. by using Swiss-ADME tool. World Scientific News, 131, 147-163. http://www.worldscientificnews.com/wp-content/uploads/2019/06/WSN-131-2019-147-163.pdf

Wahl, J., Freyss, J., von Korff, M., \& Sander, T. (2019). Accuracy evaluation and addition of improved dihedral parameters for the MMFF94s. Journal of cheminformatics, 11(1), 1-10. https://doi.org/10.1186/s13321-019$\underline{0371-6}$

Wang, J. L., Limburg, D., Graneto, M. J., Springer, J., Hamper, J. R. B., Liao, S., ... \& Carter, J. (2010). The novel benzopyran class of selective cyclooxygenase-2 inhibitors. Part 2: the second clinical candidate having a shorter and favorable human half-life. Bioorganic \& Medicinal Chemistry Letters, 20(23), 7159-7163.

https://doi.org/10.1016/i.bmcl.2010.07.054

Wehling, M. (2014). Non-steroidal anti-inflammatory drug use in chronic pain conditions with special emphasis on the elderly and patients with relevant comorbidities: management and mitigation of risks and adverse effects. European journal of clinical pharmacology, 70(10), 1159-1172. https://doi.org/10.1007/s00228-014$\underline{1734-6}$

Weinstein, D. S., Liu, W., Gu, Z., Langevine, C., Ngu, K., Fadnis, L., ... \& Murugesan, N. (2005). Tryptamine and homotryptamine-based sulfonamides as potent and selective inhibitors of 15-lipoxygenase. Bioorganic \& medicinal chemistry letters, 15(5), 1435-1440. https://doi.org/10.1016/j.bmcl.2004.12.081

Xie, W., Jiang, G., Liu, H., Hu, J., Pan, X., Zhang, H., ... \& Ma, D. (2013). Highly Enantioselective Bromocyclization of Tryptamines and Its Application in the Synthesis of (-)-Chimonanthine. Angewandte Chemie International Edition, 52(49), 12924-12927. https://doi.org/10.1002/anie.201306774

Recebido: 20 de outubro de 2021 | Aceito: 10 de janeiro de 2022 | Publicado: 04 de fevereiro de 2022

This is an Open Access article distributed under the terms of the Creative Commons Attribution License, which permits unrestricted use, distribution, and reproduction in any medium, provided the original work is properly cited. 


\section{Appendix:}

1. Compounds identification

\begin{tabular}{|c|c|c|c|c|c|}
\hline Entry & Cas Number & Entry & Cas Number & Entry & Cas Number \\
\hline TRP01 & $206449-42-5$ & TRP11 & $5912-10-7$ & TRP21 & $2292113-28-9$ \\
\hline TRP02 & $206449-41-4$ & TRP12 & $16841-85-3$ & TRP22 & $2292113-77-8$ \\
\hline TRP03 & $206449-43-6$ & TRP13 & $153029-57-3$ & TRP23 & $2292114-04-4$ \\
\hline TRP04 & $206449-35-6$ & TRP14 & $153029-59-5$ & TRP24 & $2292115-45-6$ \\
\hline TRP05 & $206449-36-7$ & TRP15 & $162127-30-2$ & TRP25 & $2292115-50-3$ \\
\hline TRP06 & $206449-51-6$ & TRP16 & $299420-53-4$ & TRP26 & $2292115-84-3$ \\
\hline TRP07 & $206449-38-9$ & TRP17 & $1374879-32-9$ & TRP27 & $2292116-00-6$ \\
\hline TRP08 & $202264-20-8$ & TRP18 & $2292111-52-3$ & TRP28 & $2299147-71-8$ \\
\hline TRP09 & $1206139-67-4$ & TRP19 & $2292111-87-4$ & TRP29 & $2299147-72-9$ \\
\hline TRP10 & $299420-52-3$ & TRP20 & $2292112-18-4$ & & \\
\hline
\end{tabular}

2. Molecular docking of selected compounds

\begin{tabular}{|c|c|c|c|}
\hline Entry & Cas Number & Entry & Cas Number \\
\hline TRP09 & -9.294 & TRP23 & -9.974 \\
\hline TRP10 & -9.317 & TRP25 & -8.955 \\
\hline TRP11 & -8.765 & TRP26 & -8.987 \\
\hline TRP16 & -9.951 & TRP28 & -9.009 \\
\hline TRP19 & -9.431 & TRP29 & -9.367 \\
\hline
\end{tabular}

